\title{
GENDER WAGE GAP IN THE CZECH REPUBLIC AND CENTRAL EUROPEAN COUNTRIES
}

\author{
Martina Mysíková*
}

\begin{abstract}
:
This paper aims to quantify the basic structure of gender wage gaps in the Czech Republic, Hungary, Poland, and Slovakia, using the EU-SILC 2008 dataset. The structure of the gender wage gap is analyzed based on the Heckman selection model and Oaxaca-Blinder decomposition. The findings are to a great extent similar for the Czech and Slovak Republics. The observed gender wage gap is relatively high in these two countries, compared to Hungary and Poland. A relatively small but positive part of the observed gender wage gap can be explained by gender differences in characteristics in the Czech and Slovak Republics, with a high contribution of job characteristics. An opposite result proved in Hungary and Poland, where working women have on average even better characteristics than working men, mainly in terms of individual characteristics.
\end{abstract}

Keywords: endowment effect, gender wage gap, Heckman model, labor market participation, Oaxaca-Blinder decomposition, remuneration effect, sample-selection effect

JEL Classification: J16, J24, J31.

\section{Introduction}

Analyzing gender-related differences between men and women in wages and labor market behavior is gradually gaining importance in Central Europe. Twenty years ago, countries of this region started to transform from communist economies into democratic regimes. Therefore, the tradition of research on gender wage inequality and labor market participation in Central Europe is relatively short compared to research on "Western countries". In order to allow judging international dis/similarities, the basic structure of gender wage gap in Central European countries needs to be quantified. Hence, this paper is concerned with gender wage gap analysis in the Czech Republic, Hungary, Poland and Slovakia, and uses rather recent data from the Statistics on Income and Living Conditions database (EU-SILC).

* Institute of Economic Studies, Charles University in Prague, and Institute of Sociology of the Academy of Sciences, Prague (martina.mysikova@centrum.cz).

This paper was written with the support of the Grant Agency of the Czech Republic, Grant No. P404/11/1521 (Well-being and Satisfaction of Households in CEE Countries: Linking Objective and Subjective Indicators). The author wishes to thank Michael Coelli (The University of Melbourne, Australia) and Vladislav Flek (Institute of Economic Studies, Charles University in Prague) for their valuable comments and advice. The usual disclaimer applies. 
Before 1989, wages were determined centrally, mainly according to demographic characteristics of workers, job tenure, physical demand in some industries, ideological importance of certain jobs, etc. Although communist Czechoslovakia was a country with one of the highest wage equalization in the world, differences in earnings were still to a high extent influenced by gender (Večerník, 2009). According to Večerník's earlier study (Večerník, 1986), gender earnings discrepancy was enhanced by the fact that industries and jobs typically occupied by women were disfavored by the system. Moreover, women were remunerated with lower wage tariffs for comparable work, and non-tariff components of wages were also lower for women. In former Czechoslovakia, the average female-male wage ratio varied only slightly, from $65.8 \%$ in 1960 to $68.4 \%$ in 1979, and did not show any substantial differences between countries (Večerník, 1986).

After 1989, during the transition period, wages started to reflect education, experience, and skills, and earnings inequality began to grow. The most substantial changes in earnings distribution in transitions countries occurred in the first half of the 1990s. According to Rutkowski (2001), the factors that contributed the most to the rising income inequality in transition countries during the 1990s were education and interindustry wage differentials, while other factors, like gender or work experience, were less important, or even insignificant.

Indeed, the gender wage differentials started to shrink in transition countries after 1989. Newell and Reilly (2001) show that female-male ratio of monthly earnings increased markedly between the second half of 1980s and 1996 in Central European countries. At the end of the communist era, gender wage inequality in former Czechoslovakia was one of the highest among the countries analyzed in this paper: the female-male wage ratio was $66.1 \%$ in 1987, while it amounted to approximately $74 \%$ in Hungary and Poland. In 1996, the female-male wage ratio was almost balanced in these four countries, with around $80 \%$.

The development of gender wage inequality in these countries started to diverge as early as in the late 1990s. While the female-male average wage ratio decreased in the Czech Republic, it increased to roughly 85\% in 1999 in Poland. Only after 2002 the situation of Hungarian women started to develop in their favor and the ratio reached $84 \%$. However, the values persisted at roughly $75 \%$ in the Czech Republic and Slovakia even in 2005 (about 90\% in Poland and Hungary at that time). To put it in simple terms, the gender wage difference has been substantially diminishing in Poland and Hungary while it has remained the same or even slightly deteriorated before 2005 in the Czech Republic and Slovakia. ${ }^{1}$

Analyzing the differences between average male and female wages does not say much about the real situation of women on the labor market. The observed gender wage gap only captures the wages of individuals selected into employment. The substantial decrease of gender wage gap over the transition period might have been at least

1 These figures were provided by Eurostat based on national sources. However, as the Czech statistical office provides gender median wage gap to Eurostat, the female-male average wage ratios for the Czech Republic are taken from the Czech Statistical Office. 
partly caused by low-wage women withdrawing from the labor market. Hunt (2002) examined the effect of selection into employment on the gender wage gap in former Eastern Germany between the years 1990 and 1994 and showed that almost one half of the 10-percentage-point increase of female-male wage ratio in this period was due to low-skilled women leaving the labor market.

The observed gender wage gaps currently differ substantially among the analyzed Central European countries. This paper controls for selection bias using the Heckman regression method (1979) which provides us with selection-corrected estimates. The aim of this study is to reveal the explanatory factors of the observed gender wage gaps by identifying the part that can be explained by observable characteristics, and analyzing whether and to what extent such component differs in the surveyed countries. For this purpose, the Oaxaca-Blinder decomposition method is applied (see Oaxaca, 1973; Blinder, 1973).

The rest of this paper is organized as follows: The next section provides an overview on available literature. Section 3 depicts the Heckman methodology for the wage equation estimation and the Oaxaca-Blinder wage gap decomposition. Section 4 describes the EU-SILC data applied in this model and specifies the variables used, with special regard to the structure of individual and labor characteristics. Section 5 presents the results of the wage gap decomposition; specifically, it provides quantitative estimates of factors determining the gender wage gaps. Section 6 summarizes the main results.

\section{Literature Overview}

The empiric literature on gender wage differentials is relatively rich. The common procedure of gender wage gap structure analysis is first to reveal the selection effect. ${ }^{2}$ In addition to the selection effect, further two basic effects can be determined: The endowment effect is caused by differences in skills, education and in other individual labor or job characteristics between men and women. Typically, women and men differ in terms of their human capital characteristics, they are concentrated in different occupations or industrial branches, and, based on such endowment differences, they are often remunerated differently. The remaining part of the observed gender wage gap could be explained by the remuneration effect caused by the gender-specific remuneration of the same individual and job characteristics. This effect is often associated with discrimination, but it should rather be considered an unexplained part of the observed wage gap. This part of the gap may still be formed by unobserved differences in individual or other characteristics, and only an unknown fraction of the remuneration effect can be attributed to discrimination. ${ }^{3}$

2 The selection effect results from a correction of the sample selection bias that occurs when working individuals do not create a random sub-sample of the population but differ systematically from nonparticipating individuals (Beblo et al., 2003).

3 While I use the original terminology, terms like "explained and unexplained parts" or "gender differences in characteristics and gender differences in the returns to characteristics" to refer to the endowment and remuneration effects might be used by other authors. 
The study most closely related to the present paper is that of Beblo et al. (2003). It uses the Heckman (1979) and Lewbel (2005) selection models along with European Community Household Panel (ECHP) data to estimate the selection-corrected wage gap. The authors claim that the selection effect is negative (more than $40 \%$ ) in the EU, which means that the entry of non-participating individuals into labor market would cause a 40-percent increase in the observed gender wage gap. ${ }^{4}$ The endowment effect in the EU represents almost $20 \%$ of the observed gender wage gap. The authors as well as the other existing literature usually evaluate the unexplained part of the observed gender wage gap as a rather large one.

Many analyses of the selection bias and various correction methodologies have emerged since the aforementioned Heckman's seminal study (1979). The majority of these extend Heckman's classic model to allow for non-normality. Blundell et al. (2007) examine changes in the distribution of wages in the UK using bounds to allow for the impact of non-random selection into work. The method of Blundell et al. requires fewer assumptions than the Heckman's model but is unfortunately rather less precise. Most studies confirming the importance of selection are based on US data (see, for example, Neal, 2004; Blau and Kahn, 2006; and Mulligan and Rubinstein, 2005), while fewer studies on this problem concern the European environment.

Olivetti and Petrongolo (2008) compare the observed gender wage gaps with the selectioncorrected ones for the pre-enlargement EU Member States using several imputation methods and the ECHP data. The advantage of their method is that it does not rely on distributional assumptions as heavily as the Heckman model. They confirm a negative relationship between the gender employment gap and the observed gender wage gap in all surveyed countries (see also OECD, 2002). The selection effect proves to be highly negative in Southern European countries, with the highest differences between male and female employment rates. Thus, large inflows of non-participating individuals into the labor market would cause relatively high increases in the observed gender wage gap. By contrast, in Scandinavian countries, with low differences between male and female employment rates, the selection effect is positive, i.e. the inflow of non-participating individuals would bring about decrease of the observed gender wage gap.

Albrecht et al. (2004) use quantile regressions to estimate the gender wage gap in the Netherlands. They apply the method introduced by Buchinsky (1998) to correct for sample selection in quantile regression. Albrecht et al. apply a rather innovatory approach, as they extend the quantile regression decomposition procedure to control

4 Adding information on sectoral occupation to the list of explanatory variables significantly lowers the negative selection effect reported by Beblo et al. (2003), to almost $10 \%$ of the observed gender wage gap. The Heckman procedure applied by Beblo et al. (2003) on German data shows a different picture: the selection effect is actually positive by more than $10 \%$. This indicates that without selection the wage gap in Germany would be lower than the observed one. 
for selection. ${ }^{5}$ They found out that a larger part of the gender wage gap is caused by gender differences in returns to labor market characteristics, while about one third on average is due to differences in these characteristics.

Similar study was performed by Nicodemo (2009). Using the selection-corrected quantile regression and data from the ECHP 2001 and EU-SILC 2006, she analyzed the selection-corrected gender wage gap for wives and husbands in five Mediterranean countries. She showed that the gender wage gap decomposition differs if selection into employment is ignored. The part of the gender wage gap caused by gender differences in characteristics proved to be very small, while the greater part was caused by the discrimination effect.

The most comprehensive studies on the gender wage gap in the Czech Republic are those of Jurajda $(2003,2005)$ and are concerned mainly with segregation effects. Jurajda used data from 1998 and, most importantly, showed that one-third of the observed gender wage gap is caused by unequal male and female representation in a particular occupation in both the Czech Republic and Slovakia. As opposed to Jurajda's research, the present paper controls for selectivity and deals with the selection-corrected gender wage gap.

Based on the above discussed conceptual framework, the following general propositions can be formulated: (i) The selection effect will probably be negative, as mainly low-wage women are likely to stay out of the labor force. However, according to Olivetti and Petrongolo (2008), we might even expect a positive selection effect in Slovakia, a country with the lowest gender employment gap (see Table 2). (ii) In the labor market, women with better wage characteristics prevail and therefore the average characteristics of working men and women are expected to be similar, with a relatively small endowment effect as a consequence. Its extent varies in the above mentioned literature, from negative values (e.g. Nicodemo, 2009, for Portugal) to roughly one third in the study of Albrecht et al. (2004) for the Netherlands. (iii) Consequently, a large part of the gender wage gap is likely to be attributed to the remuneration effect (possibly also to other unexplained factors).

Although intuitive enough from a conceptual viewpoint, these propositions should be tested empirically in a rigorous manner to deliver a well-structured analysis of gender wage inequality in the four surveyed labor markets. This paper applies the OaxacaBlinder decomposition method (Oaxaca, 1973; Blinder, 1973), including selectioncorrected estimates of female wages, to quantify the above mentioned effects.

5 I am aware that techniques such as quantile regression might be more informative than the Heckman model used here. The advantage of a quantile regression is that rather than identifying differences at the mean of the distribution, they are explained quantile by quantile. This certainly represents a future direction for the gender wage gap research in Central Europe. Still, as a first step I find it valuable to follow the traditional approach. 


\section{Methodology}

The existing literature offers many ways of examining the factors that influence the gender wage gap (Becker, 1964; Mincer and Polachek, 1974; Eckstein and Wolpin, 1989; Wright and Ermisch, 1991). Recent studies (e.g., Albrecht et al., 2004; Olivetti and Petrongolo, 2008; Mulligan and Rubinstein, 2004) apply various selectioncorrected methods. Much of this work develops the classic Heckman (1979) model.

The Heckman procedure is a two-stage model. First, a probit model for the probability of working is applied. In the second stage, predicted individual probabilities are added as an explanatory variable to the wage equation. ${ }^{6}$ If the unobservables in the participation equation are correlated with the unobservables in the wage equation, the estimates without correction (in an OLS model) would be biased. This basically means that the unobservables in the selection (or choice) of working affect also the wage equation. In other words, selection into the sample of working individuals is a non-random process, affected by different unobservables. The estimated wage function under the selectioncorrected Heckman model is:

$$
\ln W_{i}=X_{i} \beta+\rho \sigma_{\varepsilon} \lambda_{i}+\varepsilon_{i}^{*}, \text { where } \lambda_{i}=\frac{\varphi\left(V_{i} y\right)}{\Phi\left(V_{i} y\right)}
$$

Vector $X_{i}$ includes all explanatory variables of the wage equation, $\varphi$ and $\Phi$ signify standard normal density and distribution functions, respectively, $V_{i}$ represents the vector of explanatory variables of the participation equation that should differ from the one included in the wage equation, $\rho$ is the correlation coefficient of the wage and participation equations and $\sigma_{\varepsilon}$ is the standard deviation. ${ }^{7}$

A positive $\rho$ indicates that unobservables in the wage and participation equations are positively correlated. For example, let us take ability as one unobservable in a wage equation. If ability is positively related to both participation and wages, the $\rho$ is positive. Negative $\rho$ means that an unobservable in the wage equation is negatively related to participation, while positively to wage. For instance, if handsomeness is an unobservable in the wage equation and is negatively related to decision to participate but positively to wages, $\rho$ will be negative.

6 Except the addition of working probability the estimation corresponds to commonly used Minceriantype wage equations (Mincer, 1974), where the (logarithmic) earnings profile is a function of years of schooling, concave function of experience and further supplemented by the impact of other relevant individuals and job characteristics.

7 For more details, see Heckman (1979) or some of the studies reproducing Heckman's model (e.g., Beblo et al., 2003). The model does not treat a possible endogeneity of some variables, such as education, because of the lacking consensus in literature on how to instrument variables of this type. Moreover, suitable instrumental variables are usually unavailable in commonly applied datasets. That is why a similar kind of objection can be attributed to practically all empirical literature on the gender wage gap decomposition. 
Using the coefficients estimated from the male and female wage equations, the observed gender wage gap can be decomposed into several effects. The best-known decomposition method is the Oaxaca-Blinder method (Oaxaca, 1973; Blinder, 1973). The observed gender wage gap is defined as:

$$
\begin{aligned}
& \overline{\ln W^{M}}-\overline{\ln W^{F}}=\left(\overline{\ln W^{M}}-\overline{\ln W^{1 F}}\right)+\left(\overline{\ln W^{1 F}}-\overline{\ln W^{F}}\right) \\
& =\left(\overline{X^{M}} \hat{\beta}^{M}-\overline{X^{F}} \hat{\beta}^{M}\right)+\left(\overline{X^{F}} \hat{\beta}^{M}-\overline{X^{F}} \hat{\beta}^{F}\right) \\
& =\underbrace{\left(\overline{X^{M}}-\overline{X^{F}}\right) \hat{\beta}^{M}}+\underbrace{\overline{X^{F}}\left(\hat{\beta}^{M}-\hat{\beta}^{F}\right)} \\
& \text { endowment effect remmuneration effect }
\end{aligned}
$$

where expressions with a bar signify mean values. The term $\overline{\ln W^{1 F}}$ represents the average hypothetical female wage if the female individual and job characteristics were remunerated in the same way as male.

The term $\left(\overline{X^{M}}-\overline{X^{F}}\right) \hat{\beta}^{M}$ on the right-hand side of the equation (2) represents the endowment effect and determines the extent to which the average male wage would exceed the average hypothetical female wage if the individual and job characteristics of men and women were remunerated in the same way (that is, if there were no discrimination). This part of the observed gender wage gap is therefore supposed to reflect the differences in productivity between men and women.

The term $\overline{X^{F}}\left(\hat{\beta}^{M}-\hat{\beta}^{F}\right)$ represents the remuneration effect and shows the disparity between the hypothetical and observed female average wages. In other words, had the female and male characteristics been remunerated in the same way, the remuneration effect would be zero. If men and women had the same average characteristics, the observed wage gap would be given only by the remuneration effect.

To correct the sample selection bias, it is necessary to add another component to the decomposition equation (2) - the selection effect. The selection effect reveals the way in which the observed gender wage gap would change if non-participating individuals started working. The transformed equation (2) then takes on the following form:

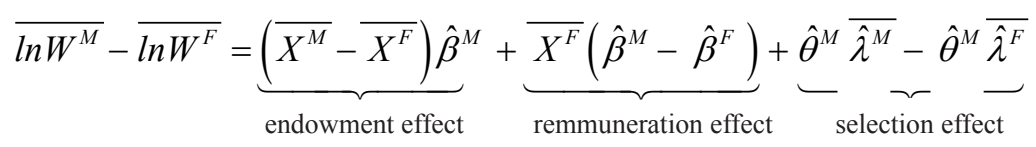

where $\hat{\theta}$ is the estimate of $\rho \sigma_{\varepsilon}$ and $\overline{\hat{\lambda}}$ is the average estimated $\lambda_{i}$ from Heckman's equation (1).

The standard OLS regression method is used for men in some studies (see, for example, Beblo et al., 2003). As the participation rate of men in the sample is close to $100 \%$, the male sample selection is random in the above quoted study. Since the employment participation of men is relatively high in the samples used in the present analysis, it should not be affected by selectivity problems. ${ }^{8}$ Therefore, male wage equations are

8 See Table 2. 
estimated by OLS. If a random sample for men is assumed, the correction term for men in equation (3), i.e., $\hat{\theta}^{M}$, is set to zero.

Positive selection effect, i.e. negative $\hat{\theta}^{F}$, corresponds to a negative selection on unobservables (negative correlation between the unobservables in female wage and participation equations). ${ }^{9}$ It means that the selection-corrected gender wage gap would be lower than the observed one if people who are currently not working had the same observed characteristics as those who currently are working. However, due to different endowments of participating and non-participating women, this does not necessarily imply that if all women worked, their average wage would be higher. The selection effect deals with unobservables. Therefore, the positive selection effect occurs when non-participating women possess better unobserved characteristics than working women in terms of wage remuneration.

A positive selection on unobservables, i.e. positive $\hat{\theta}^{F}$ and negative selection effect, suggests that actual wages of working women are higher than hypothetical wages of a random female population sample with a comparable set of observed characteristics. Negative selection effect arises when non-participating women have worse unobserved characteristics than working women, e.g., lower abilities affecting both their probability of participation and potential wage.

\section{The Data}

The EU-SILC household survey is a new panel survey that replaced its predecessor ECHP in 2004. It is a uniform survey compulsory for all EU Member States, and therefore provides data suitable for cross-country comparisons. The collected information concerns households (mainly information on living conditions) and individuals (individual and job characteristics, wages, income, and social allowances).

This study is based on data from EU-SILC 2008 for the Czech Republic, Hungary, Poland, and Slovakia. Full-time students, permanently disabled individuals, self-employed, and unemployed have been excluded from the sample. Students and disabled have been excluded because their job choices are limited, while the self-employed are eliminated since their highly fluctuating earnings would make the analysis biased. Typically, the unemployed are excluded from the sample as well (see Beblo et al., 2003), as their individual characteristics, and consequently their job search effort, is usually significantly different from those of the inactive population. Joining both the inactive and unemployed would create a heterogeneous group inappropriate for the model. ${ }^{10}$

9 As $\sigma_{\varepsilon}$ is positive by definition, the sign of $\hat{\theta}$ is the same as the sign of $\rho$.

10 As an alternative, a double selection into participation could in principle be done: one for being unemployed, the other for being inactive. The reason is that part of the unemployed might equally be discouraged from labor market participation as the inactive population. However, the information on unemployment status in the dataset is self-reported and, hence, lacks the information about the nature of unemployment (voluntary or involuntary). Therefore, the group of unemployed itself seems to be heterogeneous enough and is typically excluded from the sample without aspiring on double selection exercises. 
Table 1

Sample Characteristics (weighted)

\begin{tabular}{|c|c|c|c|c|c|c|c|c|}
\hline & \multicolumn{2}{|c|}{$\mathrm{CZ}$} & \multicolumn{2}{|c|}{ HU } & \multicolumn{2}{|c|}{ PL } & \multicolumn{2}{|c|}{ SK } \\
\hline & Male & Female & Male & Female & Male & Female & Male & Female \\
\hline \multicolumn{9}{|c|}{ WAGE EQUATION: } \\
\hline$N$ (unweighted) & 4070 & 3657 & 2751 & 2586 & 4308 & 4098 & 2693 & 2652 \\
\hline LN WAGE & 1.50 & 1.25 & 1.19 & 1.10 & 1.27 & 1.18 & 1.21 & 1.01 \\
\hline EDUC_YEARS & 13.77 & 13.74 & 13.88 & 14.31 & 13.71 & 14.69 & 13.93 & 14.10 \\
\hline YEARS_WORK & 16.99 & 17.88 & 16.90 & 19.79 & 15.83 & 15.04 & 17.35 & 19.16 \\
\hline YEARS_WORK2 & 389.51 & 424.22 & 386.03 & 498.71 & 363.53 & 331.48 & 413.81 & 473.50 \\
\hline SIZE_10 & $14.41 \%$ & $21.83 \%$ & $24.36 \%$ & $26.80 \%$ & $36.48 \%$ & $38.40 \%$ & $33.51 \%$ & $40.89 \%$ \\
\hline SIZE_11_49 & $38.76 \%$ & $37.88 \%$ & $33.27 \%$ & $33.92 \%$ & $25.48 \%$ & $26.21 \%$ & $46.52 \%$ & $40.52 \%$ \\
\hline CONTRACT & $90.71 \%$ & $88.66 \%$ & $92.83 \%$ & $93.05 \%$ & $76.73 \%$ & $77.34 \%$ & $91.55 \%$ & $90.91 \%$ \\
\hline SUPERVISOR & $23.08 \%$ & $13.03 \%$ & $21.73 \%$ & $16.52 \%$ & $21.03 \%$ & $17.89 \%$ & $16.26 \%$ & $11.67 \%$ \\
\hline PRAGUE & $11.47 \%$ & $12.64 \%$ & - & - & - & - & - & - \\
\hline DENSE_AREA & - & - & $34.75 \%$ & $36.61 \%$ & $43.99 \%$ & $49.78 \%$ & $27.23 \%$ & $30.84 \%$ \\
\hline ISCOO & $1.16 \%$ & - & $2.39 \%$ & - & $1.00 \%$ & - & - & - \\
\hline ISCOI & $5.17 \%$ & $2.54 \%$ & $6.00 \%$ & $4.14 \%$ & $4.80 \%$ & $4.34 \%$ & $6.57 \%$ & $3.31 \%$ \\
\hline ISCO2 & $8.34 \%$ & $9.42 \%$ & $10.05 \%$ & $16.32 \%$ & $9.76 \%$ & $25.40 \%$ & $9.76 \%$ & $16.03 \%$ \\
\hline ISCO3 & $19.74 \%$ & $29.23 \%$ & $8.55 \%$ & $20.73 \%$ & $10.93 \%$ & $15.60 \%$ & $16.17 \%$ & $29.56 \%$ \\
\hline ISCO4 & $4.23 \%$ & $15.86 \%$ & $5.32 \%$ & $14.47 \%$ & $5.47 \%$ & $14.38 \%$ & $4.42 \%$ & $13.99 \%$ \\
\hline ISCO5 & $8.31 \%$ & $18.84 \%$ & $11.10 \%$ & $18.15 \%$ & $6.91 \%$ & $17.88 \%$ & $9.12 \%$ & $16.27 \%$ \\
\hline ISCO6 & $1.43 \%$ & $1.19 \%$ & $1.80 \%$ & $0.83 \%$ & $0.76 \%$ & $0.20 \%$ & $0.81 \%$ & $0.58 \%$ \\
\hline ISCO7 & $30.03 \%$ & $7.91 \%$ & $30.03 \%$ & $7.57 \%$ & $32.49 \%$ & $6.23 \%$ & $26.55 \%$ & $5.97 \%$ \\
\hline ISCO8 & $17.61 \%$ & $5.89 \%$ & $19.70 \%$ & $8.41 \%$ & $20.34 \%$ & $5.10 \%$ & $20.16 \%$ & $6.25 \%$ \\
\hline \multicolumn{9}{|c|}{ PARTICIPATION EQUATION: } \\
\hline $\begin{array}{l}N \\
\text { (UNWEIGHTED) }\end{array}$ & & 4569 & & 3598 & & 5796 & & 2981 \\
\hline$N O N \_E A R N \_I N C$ & & 1105.67 & & 1296.19 & & 450.75 & & 434.14 \\
\hline PARTN_W & & $66.77 \%$ & & $56.51 \%$ & & $56.43 \%$ & & $61.15 \%$ \\
\hline PARTN_NOTW & & $5.66 \%$ & & $13.94 \%$ & & $10.54 \%$ & & $6.22 \%$ \\
\hline CHILDO_2 & & $15.04 \%$ & & $17.06 \%$ & & $14.58 \%$ & & $7.49 \%$ \\
\hline CHILD3_5 & & $12.20 \%$ & & $16.34 \%$ & & $12.38 \%$ & & $8.16 \%$ \\
\hline CHILD6_15 & & $30.07 \%$ & & $32.18 \%$ & & $32.69 \%$ & & $29.21 \%$ \\
\hline EDUC_YEARS & & 13.73 & & 14.08 & & 14.25 & & 14.01 \\
\hline AGE_30 & & $27.94 \%$ & & $28.97 \%$ & & $31.24 \%$ & & $25.13 \%$ \\
\hline age_31_45 & & $46.48 \%$ & & $42.51 \%$ & & $40.16 \%$ & & $40.20 \%$ \\
\hline
\end{tabular}

Source: EUSILC UDB 2008 - version 1 of March 2010. Author's computations.

Note: *Variable YEARS_W (and its square) is unavailable in Hungary. A proxy variable computed as "age - 6 EDUC_Y' (and its square) used instead. 
These restrictions have been applied in order to form a homogenous sample consisting of the employed and a fraction of those who stay "voluntarily" out of the labor market (inactive). In addition, the age limit 16-55 has been employed in order to avoid retirement choices. The samples included in our analysis are described in Table 1. The data is weighted by individual weights reflecting the number of people in the whole population represented by a particular individual in the sample. Robust variance estimates are used.

The dependent variable in the Heckman model is the logarithm of the hourly gross wage. It is not obtained directly; it is computed on the basis of the Eurostat definition of the gender wage gap. ${ }^{11}$ The difference between male and female mean wages, i.e. the observed gender wage gap, is positive but relatively small in Hungary and Poland, while it gains substantial values in both Czech Republic and Slovakia.

Table 2

Observed Gender Wage Gap and Employment Rates (\%) - in Sample Applied

\begin{tabular}{|l|c|c|c|c|}
\hline & $\begin{array}{c}\text { Gender wage } \\
\text { gap }\end{array}$ & $\begin{array}{c}\text { Male } \\
\text { Employment }\end{array}$ & $\begin{array}{c}\text { Female } \\
\text { Employment }\end{array}$ & $\begin{array}{c}\text { Employment gap } \\
\text { (pp.) }\end{array}$ \\
\hline CZ & 22.6 & 99.1 & 79.6 & 19.5 \\
\hline HU & 8.9 & 94.3 & 73.0 & 21.3 \\
\hline PL & 8.6 & 91.5 & 72.7 & 18.8 \\
\hline SK & 18.4 & 96.3 & 89.1 & 7.2 \\
\hline
\end{tabular}

Source: EUSILC UDB 2008 - version 1 of March 2010. Author's computations.

The following explanatory variables are included in the male and female wage equations: ${ }^{12}$ EDUC_YEARS states the number of years spent in school. On average, working women have studied longer in all of the examined countries, with the exception of the Czech Republic. YEARS_WORK gives the total number of years' experience, and YEARS_WORK2 is its square. The Hungarian dataset lacks this variable; therefore, a proxy "age minus 6 minus years in education" was applied.

SIZE_10 and SIZE_11_49 represent dummies equaling 1 if the employee works in a local unit with a maximum number of 10 , or 11-49 workers, respectively, and 0 otherwise. CONTRACT is a dummy variable that equals 1 if the employee has an unlimited job contract and 0 otherwise. On average, Czech and Slovak working men enjoy more often a job contract of unlimited duration than women. The opposite

11 The hourly gross wage is the usual monthly gross income from a person's main job divided by the quadruple of the number of hours usually worked per week in the person's main job, including common overtime.

12 Ideally, the list of control variables should contain other variables that might account for gender wage differences like working conditions, job flexibility, state or private sector, unionization etc. Unfortunately, the data available does not provide such information. 
holds for Hungary and Poland, i.e. the two countries with small observed wage gaps. SUPERVISOR is a dummy for a managerial position; it equals one if the employee's position is supervisory, and 0 otherwise. In all covered countries men tend to more often occupy jobs with supervisory responsibilities then women.

PRAGUE is a dummy variable equaling 1 for individuals living in the region of the Czech capital. Wages in the capital are typically rather higher than wages in other areas of the country. ${ }^{13}$ Unfortunately, similar distinction cannot be deduced from Hungarian, Polish, and Slovak datasets, since they contain less detailed information on regional units (only NUTS1 codes). This is why the DENSE_AREA variable, a dummy corresponding to living in larger cities, has been applied instead. ${ }^{14}$ ISCOm is a dummy variable for occupational groups, where $m=0$ to $8 .{ }^{15}$

The explanatory variables included in the female participation equations are the following: NON_EARN_INC is the total annual non-earned household income. ${ }^{16}$ PARTN_W and PARTN_NOTW are dummies for living with a working, or not working partner. The counterpart to these variables is living without any partner. CHILDO_2, CHILD3_5, and CHILD6_15 are dummy variables indicating the presence of a child of a corresponding age. Household characteristics serve as the exclusion restriction that do not enter wage equations, i.e. they are the variables that affect participation in the labor market without affecting wages conditional on participating.

EDUC_YEARS is again the number of years spent in school. This time the samples include both working and inactive women. For this sample the average number of years of education is slightly lower than for working women. $A G E \_30$ and $A G E 31 \_45$ are dummy variables for corresponding age; the highest age-group is omitted. The sample characteristics are summarized in Table 1.

13 The wage disparity between Prague and other regions is substantial, while the differences among other regions are rather negligible. The average wage in the Prague region was approximately $33,500 \mathrm{CZK}$ in 2007 while the average wages in other regions ranged between 21,500 and 25,000 CZK (Czech Statistical Office, 2008).

14 As a densely populated area is considered a local unit which has a density superior to 500 inhabitants per square kilometer and where the total population for the unit is at least 50,000 inhabitants.

15 The ISCO occupational classification code divides employees into 10 groups. ISCOO - Armed forces; ISCO1 - Legislators, senior officials and managers; ISCO2 - Professionals; ISCO3 Technicians and associate professionals; ISCO4 - Clerks; ISCO5 - Service workers and shop and market sales workers; ISCO6 - Skilled agricultural and fishery workers; ISCO7 - Craft and related trades workers; ISCO8 - Plant and machine operators and assemblers; ISCO9 - Elementary occupations. The last group is dropped due to collinearity. The dummy variable ISCOO is also dropped among women and in Slovakia, because in this group there are no or almost no individuals in the samples.

16 This variable includes income from rental of a property or land, interest, dividends and profit from capital investments, regular inter-household cash transfer received, family and children related allowances, housing allowances, and other benefits related to social exclusion. Unfortunately, not all countries stated net income variables values in the EU-SILC survey. Therefore, NON_EARNED_ INC represent gross annual values in euro. 


\section{Decomposition Results}

The actual observed gender wage gap, expressed as the difference between male and female mean hourly log-wage (the expression on the left-hand side of equation (3)), is the highest in the Czech Republic, where it amounts to $0.256 \log$ points, followed by Slovakia with $0.204 \log$ points. In Hungary and Poland, the observed gender wage gap exhibits much lower values (0.093 and $0.089 \log$ points, respectively). This figure represents the observed wage gap between working men and women.

The Oaxaca-Blinder decomposition points to a negative selection effects in the Czech Republic and Hungary (see Graph 1). It amounts to mere -0.002 log points in the Czech Republic, i.e. the selection effect represents $-0.7 \%$ of the observed gender wage gap in the Czech Republic, while representing as much as $-0.019 \log$ points, i.e. $-20.9 \%$, in Hungary. This reveals that the selection-corrected gender wage gap would be higher than the actual one, by $0.7 \%$ in the Czech Republic and $20.9 \%$ in Hungary, if currently not working women had the same observed characteristics as those currently working.

The opposite occurs in Poland and Slovakia, where the selection effect appears positive with $0.019 \log$ points $(21.7 \%)$ in Poland and $0.011 \log$ points (5.3\%) in Slovakia. This means that in Poland and Slovakia the selection effect accounts for $21.7 \%$ and $5.3 \%$ of the observed gender wage gap, respectively. Hence, the observed gender wage gap exceeds the selection-corrected one.

The results of the Heckman regression model for women, as well as OLS model for men, are reported in Annex. The results for the Czech Republic and Hungary showed $\theta^{F}$ positive (i.e. positive selection, meaning positive correlation between unobservables in the participation equation and in the wage equation). Negative THETA for women, i.e. positive selection effect, corresponding to a negative selection on unobservables, was detected in Slovakia and Poland. Hence, the selection-corrected gender wage gap would be lower than the observed one. Olivetti and Petrongolo (2008) claim this can particularly be observed in countries with a small difference between male and female employment rates. Their findings are supported by results reported for Slovakia, where the gender employment gap within the sample is the lowest among the surveyed countries (see Table 2). However, the same explanation does not fully apply to Poland, where the gender employment gap is rather high (although still lower than in the Czech Republic and Hungary).

If the average characteristics of working women and men were the same, the endowment effect would be zero. The decomposition results reveal a positive endowment effect both in the Czech Republic (0.025 log points) and Slovakia (0.009). This indicates that the difference in characteristics of working men and women account for $10.0 \%$ of the Czech and $4.2 \%$ of the Slovak observed gender wage gap. ${ }^{17}$

17 These results indicate a higher positive endowment effect than the earlier attempt to decompose the observed gender wage gap in the Czech Republic in 2005 (see Mysíková, 2007) where it exhibits almost zero, and even slightly negative, endowment effect. The present study includes more explanatory variables into the wage equation (size of the company and supervisory position) which can be considered to be the main source of the difference. 


\section{Graph 1}

\section{Observed Gender Wage Gap Decomposition}

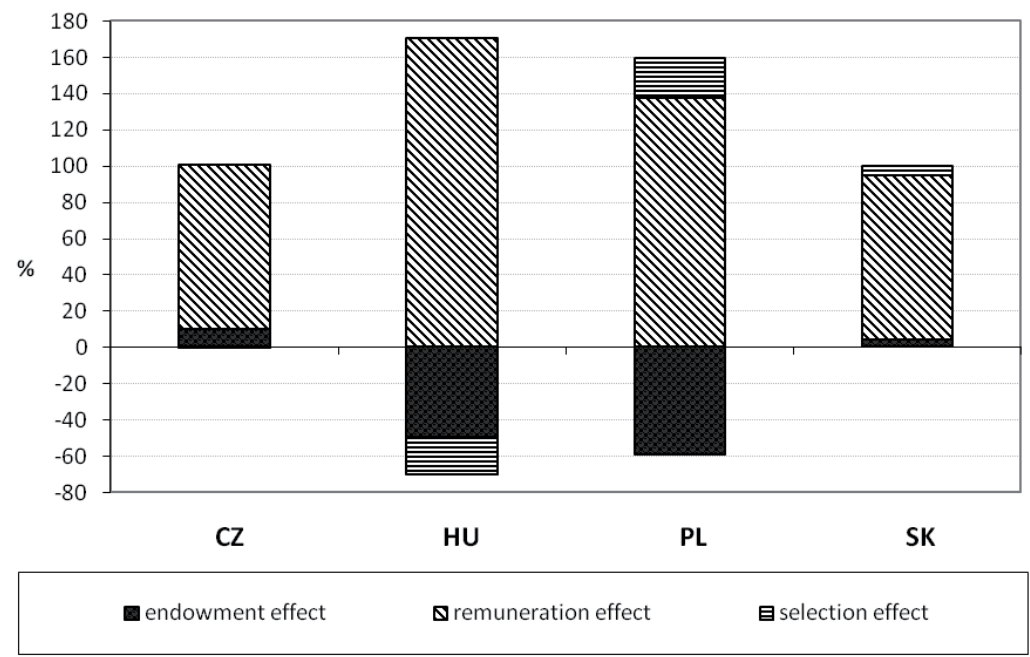

Source: EUSILC UDB 2008 - version 1 of March 2010. Author's computations.

In Hungary and Poland, the endowment effect shows a negative value (-0.046 and $-0.053 \log$ points, which is $-49.4 \%$ and $-59.2 \%$ of the observed gender wage gap, respectively). This means that working women have even better characteristics than working men.

Table 3 provides a more detailed description of the endowment effect. The individual characteristics contribute negatively to the endowment effect, which means that working women have better individual characteristics in all countries. It is the job characteristics that form the positive endowment effect both in the Czech Republic and Slovakia. This suggests that, compared to women, working men have generally better work conditions, e.g. more often work in large companies, more often profit from an unlimited job contract and occupy supervisory positions in their jobs.

To the contrary, the negative endowment effect in Hungary is almost entirely determined by individual characteristics, whereas job characteristics have barely any impact at all. With a negative endowment effect, Hungarian working women have on average better individual characteristics. On the other hand, their job characteristics are comparable to those of working Hungarian men. In Poland, both individual and job characteristics contribute negatively to the total endowment effect. Individual characteristics form two thirds of the endowment effect, while job characteristics are only responsible for one third. 
Table 3

Observed GWG, Endowment Effect and Individual and Job Characteristics Contribution

\begin{tabular}{|c|c|c|c|c|}
\hline & CZ & HU & PL & SK \\
\hline Observed GWG (\%) & 22.6 & 8.9 & 8.6 & 18.4 \\
\hline Observed GWG (log points) & 0.256 & 0.093 & 0.089 & 0.204 \\
\hline Endowment effect (log points) & 0.025 & -0.046 & -0.053 & 0.009 \\
\hline Individual characteristics (log points) & -0.001 & -0.046 & -0.035 & -0.013 \\
\hline Job characteristics (log points) & 0.026 & 0.000 & -0.018 & 0.022 \\
\hline Endowment effect (\% of observed GWG) & 10.0 & -49.4 & -59.2 & 4.2 \\
\hline \multicolumn{5}{|l|}{ of which (as \% of endowment effect) } \\
\hline Individual characteristics (\%) & -2.0 & 100.8 & 66.5 & -156.4 \\
\hline Job characteristics (\%) & 102.0 & -0.8 & 33.5 & 256.4 \\
\hline Total endowment effect (\%) & 100.0 & 100.0 & 100.0 & 100.0 \\
\hline
\end{tabular}

Source: EUSILC UDB 2008 - version 1 of March 2010. Author's computations.

Notes: Individual characteristics include EDUC_YEARS, YEARS_WORK and YEARS_WORK2. Job characteristics include all other variables listed in Table A1, including PRAGUE for CZ and DENSE_AREA for other countries.

Graph 1 indicates that the remuneration effect is very high in all surveyed countries. Theoretically, if the comparable male and female characteristics were remunerated in the same way, the remuneration effect would be zero. Although working women have even better individual (and job) characteristics than working men in Hungary and Poland, men's average wages are still higher than women's. This proves that the remuneration effect amounts to more than $100 \%$ of the observed gender wage gap and that the discrimination and/or other characteristics not covered by the observed variables play a significant role in determining male and female wages.

With a caution, we can suppose that discrimination contributes partly to the remuneration effect and that the wage is to a certain extent determined by gender. The reasons for discrimination might be, for example, greater female responsibilities for family and children, employers' expectations that a young women is planning to have a family in near future, women's lower willingness to overtimes compared to men, or perhaps just employers' presumptions that average women are less productive than men.

\section{Conclusion}

The aim of this study was to quantify the basic structure of the gender wage gaps in Central Europe, an essential progress to integrating Central Europe into the discussion of gender issues in the European labor market. The highest observed gender wage gap among the surveyed countries is in the Czech Republic, followed by Slovakia. The values in these two countries substantially exceed the observed gender wage gap in Hungary and Poland. It can therefore be deduced that no uniform pattern exists in Central Europe, which proved true even after a more detailed analysis. 
This paper attempted to test three basic hypotheses. Firstly, the assumption that the selection-corrected gender wage gap will be higher than the actually observed one in all four countries, with a possible exception for Slovakia. This assumption was confirmed for Hungary and the Czech Republic. In accordance with the assumption, Slovakia proved to be the exception, as the selection effect proved to be relatively small but positive, due to comparable male and female employment rates in this country. An inflow of the inactive into employment thus would not change the observed gender wage gap in any significant way. However, the initial assumption was not confirmed for Poland, where a positive selection effect was detected with a result similar, for example, to the one found by Beblo et al. (2003) for Germany in 1998.

Secondly, the hypothesis presupposing a relatively low impact of the endowment effect on the observed gender-based wage differences has been proved for all surveyed countries. This shows that gender wage gaps do not simply result from systematically better individual and job characteristics for men. To be more specific, the endowment effect is positive and relatively low in the Czech Republic and Slovakia. In both these countries the positive endowment effect is predominantly determined by the job characteristics. Thus, working men compared to working women have generally "better" jobs. In Hungary and Poland, the endowment effect was even negative. Contrary to the Czech Republic and Slovakia, the endowment effect in Hungary was almost entirely formed by individual characteristics. The endowment effect being negative, individual characteristics of working women are on average better than those of working men, while their job characteristics are comparable. In Poland, individual characteristics form two thirds of the negative endowment effect, while job characteristics only one third. It is therefore apparent that the main gender-related problem of the labor market does not lie in inferior qualification or productivity of working women.

Finally, the remuneration effect dominates among the explanatory factors of the observed wage gaps in all investigated countries. On average, in Hungary and Poland working women have better observed characteristics than working men, yet the observed mean wages remain higher for men than for women. If remuneration was based purely on observed characteristics, women should expect to have higher wages than men. It is therefore obvious that an enormous part of the observed gender wage gap is caused by remuneration effect. Interpreting this result as an evidence of a high degree of gender-based wage discrimination would be obviously oversimplified, as other, so far unexplained, factors could contribute to a high share of the remuneration effect.

During the relatively short history of market-determined wages in the Central European countries, gender wage difference has been substantially diminishing in Poland and Hungary, while remaining the same or even slightly deteriorating in the Czech Republic and Slovakia. However, the expectations formed based on Western European empirics were mostly confirmed. Although in the analyzed countries the endowment effect seems to be comparably smaller than the one in Western Europe, the structure of gender wage gaps in these two regions have not revealed any substantial systematic differences. 


\section{Annex}

Table A1

OLS and Heckman Model

\begin{tabular}{|c|c|c|c|c|c|c|c|c|}
\hline & \multicolumn{2}{|c|}{ CZ } & \multicolumn{2}{|c|}{ HU } & \multicolumn{2}{|c|}{ PL } & \multicolumn{2}{|c|}{ SK } \\
\hline & Male & Female & Male & Female & Male & Female & Male & Female \\
\hline & OLS & Heckman & OLS & Heckman & OLS & Heckman & OLS & Heckman \\
\hline \multicolumn{9}{|c|}{ WAGE EQUATION: } \\
\hline EDUC_YEARS & $\begin{array}{c}0.042^{* \star *} \\
(0.005)\end{array}$ & $\begin{array}{l}0.044^{\star * *} \\
(0.004)\end{array}$ & $\begin{array}{l}0.087^{\star * *} \\
(0.008)\end{array}$ & $\begin{array}{c}0.077^{\star * *} \\
(0.008)\end{array}$ & $\begin{array}{c}0.040^{\star * *} \\
(0.005)\end{array}$ & $\begin{array}{c}0.048^{\star * *} \\
(0.005\end{array}$ & $\begin{array}{l}0.047^{* \star *} \\
(0.005)\end{array}$ & $\begin{array}{l}0.030^{* * *} \\
(0.004)\end{array}$ \\
\hline YEARS_WORK & $\begin{array}{c}0.026^{* * *} \\
(0.002)\end{array}$ & $\begin{array}{c}0.012^{* \star *} \\
(0.002)\end{array}$ & $\begin{array}{l}0.029^{* * *} \\
(0.003)\end{array}$ & $\begin{array}{l}0.011^{* * *} \\
(0.003)\end{array}$ & $\begin{array}{c}0.026^{* * *} \\
(0.003)\end{array}$ & $\begin{array}{c}0.018^{* * *} \\
(0.003\end{array}$ & $\begin{array}{l}0.016^{* * *} \\
(0.003)\end{array}$ & $\begin{array}{l}0.005^{\star *} \\
(0.002)\end{array}$ \\
\hline YEARS_WORK2 & $\begin{array}{c}-0.001^{* * *} \\
(0.000)\end{array}$ & $\begin{array}{c}-0.000^{* * *} \\
(0.000)\end{array}$ & $\begin{array}{c}-0.001^{* * *} \\
(0.000)\end{array}$ & $\begin{array}{l}-0.000 \\
(0.000) \\
\end{array}$ & $\begin{array}{c}-0.001^{* * *} \\
(0.000)\end{array}$ & $\begin{array}{c}-0.000^{* *} \\
(0.000\end{array}$ & $\begin{array}{c}-0.000^{\star * *} \\
(0.000)\end{array}$ & $\begin{array}{l}-0.000^{* *} \\
(0.000)\end{array}$ \\
\hline SIZE_10 & $\begin{array}{c}-0.230^{\star * *} \\
(0.019)\end{array}$ & $\begin{array}{c}-0.122^{* * *} \\
(0.015)\end{array}$ & $\begin{array}{c}-0.275^{\star \star \star} \\
(0.023)\end{array}$ & $\begin{array}{c}-0.236^{\star * *} \\
(0.022)\end{array}$ & $\begin{array}{c}-0.112^{* * *} \\
(0.019)\end{array}$ & $\begin{array}{c}-0.035^{*} \\
(0.020\end{array}$ & $\begin{array}{c}-0.190^{\star * *} \\
(0.021)\end{array}$ & $\begin{array}{c}-0.144^{* * *} \\
(0.018)\end{array}$ \\
\hline SIZE_11_49 & $\begin{array}{c}-0.104^{* * *} \\
(0.012)\end{array}$ & $\begin{array}{c}-0.065^{\star * *} \\
(0.012)\end{array}$ & $\begin{array}{c}-0.143^{\star \star \star} \\
(0.020)\end{array}$ & $\begin{array}{c}-0.128^{* * *} \\
(0.018)\end{array}$ & $\begin{array}{c}-0.166^{* * *} \\
(0.022)\end{array}$ & $\begin{array}{c}-0.045^{\star *} \\
(0.021\end{array}$ & $\begin{array}{c}-0.098^{* * *} \\
(0.019)\end{array}$ & $\begin{array}{c}-0.074^{* * *} \\
(0.017)\end{array}$ \\
\hline CONTRACT & $\begin{array}{l}-0.006 \\
(0.026)\end{array}$ & $\begin{array}{c}0.076^{\star * *} \\
(0.018)\end{array}$ & $\begin{array}{l}0.091^{* *} \\
(0.038)\end{array}$ & $\begin{array}{l}0.067^{\star *} \\
(0.031)\end{array}$ & $\begin{array}{c}0.142^{* * *} \\
(0.022)\end{array}$ & $\begin{array}{c}0.115^{* * *} \\
(0.022\end{array}$ & $\begin{array}{l}0.083^{\star \star *} \\
(0.025)\end{array}$ & $\begin{array}{l}0.057^{* *} \\
(0.023)\end{array}$ \\
\hline SUPERVISOR & $\begin{array}{c}0.136^{* * *} \\
(0.017)\end{array}$ & $\begin{array}{c}0.156^{\star * *} \\
(0.018)\end{array}$ & $\begin{array}{c}0.136^{\star * *} \\
(0.029)\end{array}$ & $\begin{array}{c}0.097^{\star * *} \\
(0.024)\end{array}$ & $\begin{array}{c}0.144^{* * *} \\
(0.025)\end{array}$ & $\begin{array}{l}0.049^{* *} \\
(0.025\end{array}$ & $\begin{array}{l}0.172^{* * *} \\
(0.025)\end{array}$ & $\begin{array}{l}0.164^{* * *} \\
(0.020)\end{array}$ \\
\hline PRAGUE & $\begin{array}{c}0.138^{* * *} \\
(0.025)\end{array}$ & $\begin{array}{c}0.174^{* * *} \\
(0.019)\end{array}$ & - & - & - & - & - & - \\
\hline DENSE_AREA & - & - & $\begin{array}{l}0.071^{\star * *} \\
(0.021)\end{array}$ & $\begin{array}{c}0.117^{* * *} \\
(0.017)\end{array}$ & $\begin{array}{c}0.094^{\star * *} \\
(0.017)\end{array}$ & $\begin{array}{c}0.064^{\star * *} \\
(0.016\end{array}$ & $\begin{array}{c}0.086^{\star * *} \\
(0.016)\end{array}$ & $\begin{array}{l}0.105^{\star * *} \\
(0.014)\end{array}$ \\
\hline ISCOO & $\begin{array}{c}0.477^{\star * *} \\
(0.051)\end{array}$ & - & $\begin{array}{c}0.515^{\star \star \star} \\
(0.064)\end{array}$ & - & $\begin{array}{c}0.573^{\star * *} \\
(0.063)\end{array}$ & - & - & - \\
\hline ISCO1 & $\begin{array}{c}0.440^{* * *} \\
(0.050)\end{array}$ & $\begin{array}{c}0.503^{* * *} \\
(0.043)\end{array}$ & $\begin{array}{c}0.478^{* * *} \\
(0.069)\end{array}$ & $\begin{array}{c}0.367^{* * *} \\
(0.062)\end{array}$ & $\begin{array}{c}0.482^{* * *} \\
(0.059)\end{array}$ & $\begin{array}{c}0.512^{\text {** }} \\
(0.060\end{array}$ & $\begin{array}{c}0.318^{* * *} \\
(0.049)\end{array}$ & $\begin{array}{c}0.436^{* * *} \\
(0.046)\end{array}$ \\
\hline ISCO2 & $\begin{array}{l}0.381^{* * *} \\
(0.040)\end{array}$ & $\begin{array}{c}0.484^{* * *} \\
(0.028)\end{array}$ & $\begin{array}{l}0.368^{* * *} \\
(0.066)\end{array}$ & $\begin{array}{c}0.376^{\star * *} \\
(0.042)\end{array}$ & $\begin{array}{c}0.506^{* * *} \\
(0.048)\end{array}$ & $\begin{array}{c}0.497^{* * *} \\
(0.035\end{array}$ & $\begin{array}{l}0.212^{* * *} \\
(0.042)\end{array}$ & $\begin{array}{l}0.360^{* * *} \\
(0.027)\end{array}$ \\
\hline ISCO3 & $\begin{array}{c}0.299^{* * *} \\
(0.033)\end{array}$ & $\begin{array}{c}0.382^{* * *} \\
(0.019)\end{array}$ & $\begin{array}{c}0.331^{* * *} \\
(0.055)\end{array}$ & $\begin{array}{c}0.333^{* * *} \\
(0.031)\end{array}$ & $\begin{array}{c}0.324^{* * *} \\
(0.038)\end{array}$ & $\begin{array}{c}0.279^{* * *} \\
(0.032\end{array}$ & $\begin{array}{c}0.259^{* * *} \\
(0.032)\end{array}$ & $\begin{array}{c}0.315^{\star * *} \\
(0.023)\end{array}$ \\
\hline ISCO4 & $\begin{array}{c}0.205^{\star \star \star} \\
(0.039)\end{array}$ & $\begin{array}{c}0.342^{\star \star \star} \\
(0.021)\end{array}$ & $\begin{array}{c}0.225^{\star \star \star} \\
(0.054)\end{array}$ & $\begin{array}{c}0.287^{\star * *} \\
(0.035)\end{array}$ & $\begin{array}{c}0.156^{\star * *} \\
(0.039)\end{array}$ & $\begin{array}{c}0.206^{\star * *} \\
(0.033\end{array}$ & $\begin{array}{l}0.108^{\star *} \\
(0.042)\end{array}$ & $\begin{array}{l}0.253^{* * *} \\
(0.024)\end{array}$ \\
\hline ISCO5 & $\begin{array}{c}0.155^{\star \star \star} \\
(0.035)\end{array}$ & $\begin{array}{c}0.095^{\star \star *} \\
(0.021)\end{array}$ & $\begin{array}{l}0.119^{* *} \\
(0.049)\end{array}$ & $\begin{array}{c}0.088^{* * *} \\
(0.029)\end{array}$ & $\begin{array}{l}0.064^{*} \\
(0.035)\end{array}$ & $\begin{array}{c}-0.056^{\star *} \\
(0.028\end{array}$ & $\begin{array}{l}0.077^{* *} \\
(0.034)\end{array}$ & $\begin{array}{l}0.050^{* *} \\
(0.025)\end{array}$ \\
\hline ISCO6 & $\begin{array}{l}-0.042 \\
(0.050)\end{array}$ & $\begin{array}{l}0.092^{* *} \\
(0.040)\end{array}$ & $\begin{array}{c}0.050 \\
(0.062)\end{array}$ & $\begin{array}{c}0.021 \\
(0.061)\end{array}$ & $\begin{array}{c}0.070 \\
(0.068)\end{array}$ & $\begin{array}{c}0.198 \\
(0.153\end{array}$ & $\begin{array}{l}-0.022 \\
(0.076)\end{array}$ & $\begin{array}{l}0.232^{* *} \\
(0.103)\end{array}$ \\
\hline ISCO7 & $\begin{array}{l}0.170^{* * *} \\
(0.029)\end{array}$ & $\begin{array}{c}0.133^{* * *} \\
(0.023)\end{array}$ & $\begin{array}{l}0.165^{\star * *} \\
(0.042)\end{array}$ & $\begin{array}{c}0.029 \\
(0.036)\end{array}$ & $\begin{array}{c}0.217^{* * *} \\
(0.028)\end{array}$ & $\begin{array}{l}-0.004 \\
(0.043\end{array}$ & $\begin{array}{l}0.176^{* * *} \\
(0.028)\end{array}$ & $\begin{array}{c}0.056^{*} \\
(0.030)\end{array}$ \\
\hline ISCO8 & $\begin{array}{c}0.136^{* * *} \\
(0.030)\end{array}$ & $\begin{array}{c}0.137^{* * *} \\
(0.027)\end{array}$ & $\begin{array}{c}0.183^{* * *} \\
(0.044)\end{array}$ & $\begin{array}{c}0.109^{* * *} \\
(0.033)\end{array}$ & $\begin{array}{c}0.201^{* * *} \\
(0.032)\end{array}$ & $\begin{array}{c}0.159^{* * *} \\
(0.034\end{array}$ & $\begin{array}{c}0.183^{* * *} \\
(0.029)\end{array}$ & $\begin{array}{l}0.117^{\text {***}} \\
(0.031)\end{array}$ \\
\hline CONSTANT & $\begin{array}{c}0.543^{* * *} \\
(0.071)\end{array}$ & $\begin{array}{c}0.231^{\text {***}} \\
(0.061)\end{array}$ & $\begin{array}{c}-0.483^{\star * *} \\
(0.112)\end{array}$ & $\begin{array}{c}-0.410^{* *} \\
(0.163)\end{array}$ & $\begin{array}{l}0.171^{* *} \\
(0.076)\end{array}$ & $\begin{array}{l}-0.040 \\
(0.089\end{array}$ & $\begin{array}{c}0.247^{* \star *} \\
(0.082)\end{array}$ & $\begin{array}{c}0.315^{\star * *} \\
(0.065)\end{array}$ \\
\hline$R 2$ & 0.354 & & 0.419 & & 0.317 & & 0.282 & \\
\hline
\end{tabular}


Table A1

OLS and Heckman Model (cont.)

\begin{tabular}{|c|c|c|c|c|c|c|c|c|}
\hline & \multicolumn{2}{|c|}{ CZ } & \multicolumn{2}{|c|}{ HU } & \multicolumn{2}{|c|}{ PL } & \multicolumn{2}{|c|}{ SK } \\
\hline & Male & Female & Male & Female & Male & Female & Male & Female \\
\hline \multicolumn{9}{|c|}{ PARTICIPATION EQUATION: } \\
\hline$N O N \_E A R N \_I N C$ & & $\begin{array}{c}-0.000^{* * *} \\
(0.000)\end{array}$ & & $\begin{array}{l}-0.000 \\
(0.000)\end{array}$ & & $\begin{array}{c}-0.000^{* * *} \\
(0.000)\end{array}$ & & $\begin{array}{c}-0.000^{* * *} \\
(0.000)\end{array}$ \\
\hline PARTN_W & & $\begin{array}{c}-0.544^{* * *} \\
(0.061)\end{array}$ & & $\begin{array}{l}-0.089 \\
(0.059)\end{array}$ & & $\begin{array}{c}-0.210^{* * *} \\
(0.029)\end{array}$ & & $\begin{array}{l}-0.086^{* *} \\
(0.037)\end{array}$ \\
\hline PARTN_NOTW & & $\begin{array}{c}-0.710^{* * *} \\
(0.112)\end{array}$ & & $\begin{array}{c}-0.441^{* * *} \\
(0.073)\end{array}$ & & $\begin{array}{c}-0.278^{* * *} \\
(0.048)\end{array}$ & & $\begin{array}{c}-0.451^{* * *} \\
(0.064)\end{array}$ \\
\hline CHILDO_2 & & $\begin{array}{c}-2.609^{* * *} \\
(0.092)\end{array}$ & & $\begin{array}{c}-2.342^{* * *} \\
(0.134)\end{array}$ & & $\begin{array}{c}-0.994^{* * *} \\
(0.050)\end{array}$ & & $\begin{array}{c}-1.286^{* * *} \\
(0.080)\end{array}$ \\
\hline CHILD3_5 & & $\begin{array}{c}-1.352^{* * *} \\
(0.074)\end{array}$ & & $\begin{array}{c}-0.752^{* * *} \\
(0.076)\end{array}$ & & $\begin{array}{c}-0.506^{* * *} \\
(0.043)\end{array}$ & & $\begin{array}{c}-0.353^{\star * *} \\
(0.068)\end{array}$ \\
\hline CHILD6_15 & & $\begin{array}{c}-0.173^{* * *} \\
(0.041)\end{array}$ & & $\begin{array}{c}-0.379^{* * *} \\
(0.066)\end{array}$ & & $\begin{array}{c}-0.225^{\star * *} \\
(0.030)\end{array}$ & & $\begin{array}{c}0.012 \\
(0.036)\end{array}$ \\
\hline EDUC_YEARS & & $\begin{array}{l}0.061^{* * *} \\
(0.011)\end{array}$ & & $\begin{array}{c}0.142^{* * *} \\
(0.011)\end{array}$ & & $\begin{array}{l}0.161^{* * *} \\
(0.005)\end{array}$ & & $\begin{array}{l}0.172^{* * *} \\
(0.008)\end{array}$ \\
\hline AGE_30 & & $\begin{array}{c}-0.490^{* * *} \\
(0.070)\end{array}$ & & $\begin{array}{c}-0.596^{* * *} \\
(0.065)\end{array}$ & & $\begin{array}{l}0.386^{* * *} \\
(0.040)\end{array}$ & & $\begin{array}{l}-0.008 \\
(0.046)\end{array}$ \\
\hline AGE_31_45 & & $\begin{array}{c}-0.047^{* * *} \\
(0.060)\end{array}$ & & $\begin{array}{l}-0.160^{* *} \\
(0.065)\end{array}$ & & $\begin{array}{l}0.526^{* * *} \\
(0.034)\end{array}$ & & $\begin{array}{c}0.294^{* * *} \\
(0.034)\end{array}$ \\
\hline CONSTANT & & $\begin{array}{c}1.612 \\
(0.168)\end{array}$ & & $\begin{array}{l}-0.188 \\
(0.174)\end{array}$ & & $\begin{array}{c}-1.456^{\star * *} \\
(0.083)\end{array}$ & & $\begin{array}{c}-0.832^{\text {***}} \\
(0.112)\end{array}$ \\
\hline Rho & & $\begin{array}{c}0.044 \\
(0.063)\end{array}$ & & $\begin{array}{c}0.236 \\
(0.367)\end{array}$ & & $\begin{array}{l}-0.118 \\
(0.096)\end{array}$ & & $\begin{array}{l}-0.223 \\
(0.065)\end{array}$ \\
\hline Sigma & & $\begin{array}{c}0.288 \\
(0.005)\end{array}$ & & $\begin{array}{c}0.337 \\
(0.012)\end{array}$ & & $\begin{array}{c}0.429 \\
(0.009)\end{array}$ & & $\begin{array}{c}0.287 \\
(0.006)\end{array}$ \\
\hline Theta & & $\begin{array}{c}0.013 \\
(0.018)\end{array}$ & & $\begin{array}{c}0.080 \\
(0.126)\end{array}$ & & $\begin{array}{l}-0.051 \\
(0.041)\end{array}$ & & $\begin{array}{l}-0.064 \\
(0.019)\end{array}$ \\
\hline$N$ of observations & 4070 & 4569 & 2751 & 3598 & 4308 & 5796 & 2693 & 2981 \\
\hline Censored obs. & & 912 & & 1012 & & 1698 & & 329 \\
\hline Uncensored obs. & & 3657 & & 2586 & & 4098 & & 2652 \\
\hline Wald chi2(16) & & 2412.00 & & 1122.57 & & 1954.10 & & 1572.63 \\
\hline Prob.>chi2 & & 0 & & 0 & & 0 & & 0 \\
\hline
\end{tabular}

Source: EUSILC UDB 2008 - version 1 of March 2010. Author's computations.

Note: Variable YEARS_W (and its square) is unavailable in Hungary. A proxy variable computed as "age - 6 EDUC_Y' (and its square) used instead.

Note: * significance at the $10 \%$ level, ${ }^{* *}$ significance at the $5 \%$ level, ${ }^{* * *}$ significance at the $1 \%$ level. Standard errors in parentheses. 


\section{References}

Albrecht, J., van Vuuren, A. and Vroman, S. (2004), "Decomposing the Gender Wage Gap in the Netherlands with Sample Selection Adjustment." IZA Discussion Paper No. 1400, Bonn: The Institute for the Study of Labor.

Beblo, M., Beninger, D., Heinze, A. and Laisney, F. (2003), "Methodological Issues Related to the Analysis of Gender Gaps in Employment, Earnings and Career Progression."

Final Project Report for the European Commission, Employment and Social Affairs DG, Mannheim: ZEW, http://ec.europa.eu/employment_social/employment_analysis/gender/gender_ fin_rep.pdf.

Becker, G. (1964), Human Capital - A Theoretical and Empirical Analysis with Special Reference to Education. Chicago: Columbia University Press.

Blau, F., Kahn, L. (2006), “The US Gender Pay Gap in the 1990s: Slowing Convergence?” Industrial and Labor Relations Review, Vol. 60, No. 1, pp. 45-66.

Blinder, A. (1973), "Wage Discrimination: Reduced Form and Structural Estimates." Journal of Human Resources, Vol. 8, No. 4, pp. 436-455.

Blundell, R., Gosling, A., Ichimura, H., Meghir, C. (2007), "Changes in the Distribution of Male and Female Wages Accounting for Employment Composition Using Bounds."Econometrica, Vol. 75, No. 2, pp. 323-363.

Buchinsky, M. (1998), "The Dynamics of Changes in the Female Wage Distribution in the USA: A Quantile Regression Approach." Journal of Applied Econometrics, Vol. 13, No. 1, pp. 1-30.

Czech Statistical Office (2008), Analysis of the Labor Market 2000-2007 (in Czech). Czech Statistical Office Publication No. 3111-08, Prague: Czech Statistical Office.

Eckstein, Z., Wolpin, K. (1989), "Dynamic Labour Force Participation of Married Women and Endogenous Work Experience." Review of Economic Studies, Vol. 56, No. 3, pp. 375-390.

Heckman, J. (2002), "Sample Selection Bias as a Specification Error." Econometrica, Vol. 47, No. 1, pp. 153-163.

Hunt, J. (1997), "The Transition in East Germany: When is a Ten Point Fall in the Gender Pay Gap Bad News?" Journal of Labor Economics, Vol. 20, No. 1, pp. 148-169.

Jurajda, Š. (2003), "Gender Wage Gap and Segregation in Enterprises and the Public Sector in Late Transition Countries." Journal of Comparative Economics, Vol. 31, No. 2, pp. 199-222.

Jurajda, Š. (2005), "Gender Segregation and Wage Gap: An East-West Comparison." Journal of the European Economic Association, Vol. 3, No. 2-3, pp. 598-607.

Lewbel, A. (2005), "Endogenous Selection or Treatment Model Estimation." Boston College Economics Department Working Paper No. 155, Boston: Boston College, http://escholarship. bc.edu/cgi/viewcontent.cgi?article=1159\&context=econ_papers.

Mincer, J. (1974), Schooling, Experience and Earnings. Columbia University Press, New York.

Mincer, J., Polachek, S. (1974), "Family Investments in Human Capital: Earnings of Women." Journal of Political Economy, Vol. 82, No. 2, pp. 76-108.

Mulligan, C., Rubinstein, Y. (2004), "The Closing Gender Gap as a Roy Model Illusion." NBER Working Paper No. 10892, Cambridge, MA: NBER.

Mulligan, C., Rubinstein, Y. (2005), "Selection, Investment, and Women's Relative Wages since 1975." NBER Working Paper No. 11159, Cambridge, MA: NBER.

Mysíková, M. (2007), “Gender Wage Gap and Its Determinants," in: Večerník, J., ed., Czech Labour Market: Changing Structures and Work Orientations. Sociological Studies 2007:4. Prague: Institute of Sociology of the Academy of Sciences.

Neal, D. (2004), "The Measured Black-white Wage Gap Among Women is Too Small." Journal of Political Economy, Vol. 112, No. 1, pp. 1-28.

Newell, A., Reilly, B. (2001), "The Gender Pay Gap in the Transition from Communism: Some Empirical Evidence." IZA Discussion Paper No. 268, Bonn: The Institute for the Study of Labor. 
Nicodemo, C. (2009), "Gender Pay Gap and Quantile Regression in European Families." IZA Discussion Paper No. 3978, Bonn: The Institute for the Study of Labor.

Oaxaca, R. (1973), "Male-Female Wage Differentials in Urban Labor Markets." International Economic Review, Vol. 14, No. 3, pp. 693-709.

OECD (2002), OECD Employment Outlook, Chapter 2: Women at Work: Who Are They and How Are They Faring? Paris: OECD.

Olivetti, C., Petrongolo, B. (2008), "Unequal Pay or Unequal Employment? A Cross-Country Analysis of Gender Gaps." Journal of Labor Economics, Vol. 26, No. 4, pp. 621-654.

Rutkowski, J. (2001), "Earnings Inequality in Transition Economies of Central Europe. Trends and Patterns during the 1990s." Social Protection Discussion Papers No. 0117, Washington: The World Bank.

Večerník, J. (1986), Mzdová a príimová diferenciace: analýza některých problemů. Prague: Ústav pro filozofii a sociologii ČSAV. (In Czech)

Večerník, J. (2009), Czech Society in the 2000s: A Report on Socio-Economic Policies and Structures. Prague: Academia.

Wright, R., Ermisch, J. (1991), "Gender Discrimination in the British Labour Market: A Reassessment." Economic Journal, Vol. 101, No. 406, pp. 508-522. 